\title{
Chemical composition and physical properties of salted shrimp paste (Kapi) produced in Thailand
}

\author{
Jaksuma Pongsetkul · Soottawat Benjakul • \\ Punnanee Sampavapol · Kazufumi Osako • \\ Nandhsha Faithong
}

Received: 7 June 2014/ Accepted: 13 August 2014/Published online: 17 September 2014

(C) The Author(s) 2014. This article is published with open access at Springerlink.com

\begin{abstract}
Chemical composition and physical properties of 11 salted shrimp pastes (Kapi) obtained from various places of Thailand were determined. Based on proximate composition, protein constituted the major component (29.44-53.27\%, dry wt. basis). All samples contained $22.77-35.47 \% \mathrm{NaCl}$ with $A_{\mathrm{w}}$ of $0.695-$ 0.774. Various formal nitrogen contents (11.96-22.87 mg N/g sample) were in agreement with different degrees of hydrolysis (12.68-20.76\%), suggesting the varying cleavage of peptides among the samples. From electrophoretic study, salted shrimp paste contained a large amount of small molecular weight proteins and peptides. Different samples had different colors with $\Delta E^{*}$ of 47.10-60.43 and $\Delta C^{*}$ of 9.46-20.76. The samples had total carotenoid content of $0.54-1.97 \mathrm{mg} / \mathrm{g}$ sample. Free astaxanthin, astaxanthin diester and canthaxanthin were the major carotenoids in salted shrimp paste. Thus, salted shrimp paste is a good source of protein and serves as the nutritious condiment.
\end{abstract}

Keywords Salted shrimp paste $\cdot$ Fermented food $\cdot$ Kapi $\cdot$ Nutrition

\section{Introduction}

Fermented fishery products are extensively consumed in Southeast Asian countries since the fifteenth century, and consumed as staples, side dishes or condiments/seasonings in daily foods. The widespread consumption of fishery fermented products over a wide geographical area throughout Southeast Asia is due to the simplicity of the processing techniques and uniformity of the final fermented products (Hajeb and Jinap 2013). Those products impart delicacy and have high nutritional value (Faithong et al. 2010).

During fermentation, raw materials are converted into products through activities of endogenous enzymes or microorganisms (bacteria, yeasts and molds). The process can be a natural process, in which desirable microorganisms grow preferentially, or a controlled process, in which isolated and characterized fermentative microorganisms (starter culture) are added to the raw material under controlled conditions (Tamang and Kailasapathy 2010). Fermentation of fishery products does not play a role in preserving them, and smaller peptides and amino acids generated can serve as nutrients for as microorganisms. Therefore, fermentation is

\footnotetext{
J. Pongsetkul · S. Benjakul $(\bowtie) \cdot$ P. Sampavapol · N. Faithong

Department of Food Technology, Faculty of Agro-Industry, Prince of Songkla University, Hat Yai, Songkhla 90112,

Thailand

e-mail: soottawat.b@psu.ac.th

K. Osako

Department of Food Science and Technology, Tokyo University of Marine Science and Technology, 5-7 Konan 4, Minatoku, Tokyo 108-8477, Japan
} 
often combined with the addition of salt or drying to reduce water activity and eliminate proteolytic and putrefying microorganisms (Chaveesak et al. 1993).

Fermentation process is also influenced by several variables including (1) the microflora present in the raw material and salt, (2) proteolytic activity of raw material and microorganism, (3) condition of the product entering the fermentation process, (4) presence or absence of oxygen, (5) nutritional state of the raw material, (6) temperature, (7) $\mathrm{pH}$ of the fermentation mixture, (8) the presence of visceral enzymes, (9) the presence and concentration of carbohydrates, and (10) the duration of the fermentation process (Phithakpol and Kasetsat 1995). Although some products have similar process, some ingredients used can be varied, leading to the different characteristics, especially flavor and taste (Mizutani et al. 1987).

$K a p i$, a typical traditional salted shrimp paste, has been widely consumed in Thailand as a condiment. Salted shrimp paste is generally prepared from the planktonous shrimp or krill (Acetes vulgaris or Mesopodopsis orientalis). Traditionally, salted shrimp paste is produced by mixing one part of salt with three to five parts of shrimp or krill. The mixture is salted, pounded and spread out on the ground to dry under sunlight. The paste is compacted and allowed to ferment in anaerobic condition at ambient temperature $\left(25-35{ }^{\circ} \mathrm{C}\right)$ for at least 1 month or longer (Faithong et al. 2010). The color of salted shrimp paste varies from a pinkish or purplish gray to a dark grayish brown. The consistency also varies, from soft and pasty to dry and hard. It could be preserved for several months (Phithakpol 1993). However, raw material, shrimp or krill/salt ratio, fermentation process and time can be varied, depending on regions or countries. This leads to different characteristics and properties of the product (Peralta et al. 2008). However, a little information regarding the chemical compositions and physical properties of salted shrimp paste (Kapi) produced in different places in Thailand has been reported. Thus, the objective of this study was to determine the chemical composition and physical properties of salted shrimp paste collected from various regions of Thailand.

\section{Methods}

Chemicals

Potassium persulfate, acrylamide, $N, N, N^{\prime}, N^{\prime}$-tetramethyl-ethylenediamine (TEMED) and bis-acrylamide were procured from Fluka Chemical Co. (Buchs, Switzerland). Sodium sulfite and ammonium thiocyanate were obtained from Riedel-de Haen (Seelze, Germany). Anhydrous sodium sulfate was obtained from Merck (Darmstadt, Germany). Isopropanol, petroleum ether and hexane were purchased from Lab-Scan (Bangkok, Thailand). Astaxanthin and $\beta$-carotene were obtained from Dr. Ehrenstorfer GmbH (Augsburg, Germany).

Samples

Salted shrimp paste samples were purchased from different provinces in Thailand, including Songkhla (2 samples), Ranong (2 samples), Krabi (2 samples), Sa-tun (1 sample), Samut Sakhon (1 sample), Rayong (1 sample), Chachoengsao (1 sample) and Samut Songkram (1 sample). Each sample was divided into several portions $\left(100 \mathrm{~g}\right.$ each), placed in polyethylene bag and heat-sealed. The samples were kept at $-20{ }^{\circ} \mathrm{C}$ and the storage time was not longer than 2 months.

Proximate analysis

Moisture, ash, fat, protein and carbohydrate contents of salted shrimp paste were determined according to AOAC methods (2000) with the analytical No. of 35.1.13, 35.1.14, 35.1.25, 35.1.15 and 35.1.16, respectively.

Determination of salt content

Salt content of salted shrimp paste was determined according to AOAC method (2000). Sample (0.5-1 g) was mixed with 10-20 ml of $0.1 \mathrm{~N} \mathrm{AgNO}_{3}$ and $10 \mathrm{ml}$ of Conc. $\mathrm{HNO}_{3}$. The mixture was boiled on a hot plate for $10 \mathrm{~min}$ and then cooled under running water. The mixture was filtered through a filter paper (Whatman No. 1) (Whatman International Ltd., Maidstone, UK). The filtrate was adjusted to the volume of $50 \mathrm{ml}$ by distilled 
water and $5 \mathrm{ml}$ of ferric alum indicator was added. The mixture was titrated with standardized $0.1 \mathrm{~N} \mathrm{KSCN}$ until the solution became permanent brownish-red. The salt content was then calculated and expressed as $\% \mathrm{NaCl}$ using the following equation:

$$
\mathrm{NaCl}(\%)=\frac{\left[\left(\mathrm{ml} \text { of } \mathrm{AgNO}_{3} \times \text { conc. of } \mathrm{AgNO}_{3}\right)-(\mathrm{ml} \text { of } \mathrm{KSCN} \times \text { conc. of } \mathrm{KSCN})\right]}{\text { Weight of sample }(\mathrm{g})}
$$

Water activity $\left(A_{\mathrm{w}}\right)$ and $\mathrm{pH}$ determination

$A_{\mathrm{w}}$ of salted shrimp paste was measured using a water activity analyzer (Thermoconstanter, Novasina, Switzerland). The $\mathrm{pH}$ of samples was measured according to the method of Nirmal and Benjakul (2009) with a slight modification. Salted shrimp paste $(3 \mathrm{~g})$ was homogenized thoroughly with 10 volumes of distilled water $(\mathrm{w} / \mathrm{v})$. The homogenate was kept at room temperature for $5 \mathrm{~min}$ prior to measurement using a $\mathrm{pH}$ meter (Sartorius, Göttingen, Germany).

Determination of formal nitrogen, ammonia nitrogen and amino nitrogen contents

\section{Formal nitrogen content}

Formal nitrogen content was determined by the titration method as described by Thai Industrial Standard (1983) with a slight modification. Salted shrimp paste $(2 \mathrm{~g})$ was mixed with $10 \mathrm{ml}$ of distilled water. Then, the mixture was homogenized at a speed of 9,500 rpm for 2 min using an IKA Labortechnik homogenizer (Selangor, Malaysia). Ten $\mathrm{ml}$ of formalin solution ( $38 \%, \mathrm{v} / \mathrm{v} ; \mathrm{pH} 9)$ were added and mixed well. The mixture was titrated with $0.1 \mathrm{~N} \mathrm{NaOH}$ to obtain $\mathrm{pH}$ of 9.0. Formal nitrogen content was calculated and expressed as $\mathrm{mg}$ formal nitrogen/g sample using the following equation:

$$
\text { Formal nitrogen content }(\mathrm{mg} \mathrm{N} / \mathrm{g})=\frac{\mathrm{ml} \text { of } \mathrm{NaOH}(\mathrm{pH} 7-\mathrm{pH} 9) \times 0.1 \times 14}{\text { Weight of sample }(\mathrm{g})}
$$

\section{Ammonia nitrogen content}

Ammonia nitrogen content was determined by the titration method as described by Thai Industrial Standard (1983) with a slight modification. Salted shrimp paste ( $2 \mathrm{~g}$ ) was placed in $400 \mathrm{ml}$ Kjeldahl flask containing $100 \mathrm{ml}$ of distilled water and $3 \mathrm{~g}$ of $\mathrm{MgO}$. The mixture was distilled and the distillate (approximately 8$10 \mathrm{ml}$ ) was collected in $50 \mathrm{ml}$ of $4 \%(\mathrm{w} / \mathrm{v})$ boric acid containing the mixed indicators $(0.125 \mathrm{~g}$ methyl red and $0.082 \mathrm{~g}$ bromocresol green in $95 \%$ alcohol $(100 \mathrm{ml}): 0.1 \%$ methylene blue in distilled water with ratio of 5:1). The solution was then titrated with $0.05 \mathrm{~N} \mathrm{H}_{2} \mathrm{SO}_{4}$ to reach the end point. Ammonia nitrogen content was calculated as follows:

$$
\text { Ammonia nitrogen content }(\mathrm{mg} \mathrm{N} / \mathrm{g})=\frac{5.6 \times 0.05 \times \mathrm{ml}^{\circ} \mathrm{H}_{2} \mathrm{SO}_{4}}{\text { Weight of sample }(\mathrm{g})}
$$

\section{Amino nitrogen content}

Amino nitrogen content was calculated based on the difference between formal and ammonia nitrogen contents (Thai Industrial Standard 1983) as follows:

$$
\text { Amino nitrogen content }(\mathrm{mgN} / \mathrm{g})=\text { Formal nitrogen content }- \text { Ammonia nitrogen content }
$$

Measurement of degree of hydrolysis (DH)

DH of salted shrimp paste was determined according to the method of Benjakul and Morrissey (1997). The sample $(1 \mathrm{~g})$ was mixed with $9 \mathrm{ml}$ of $5 \%(\mathrm{w} / \mathrm{v})$ SDS. The mixture was homogenized at a speed of 11,000 rpm 
for $1 \mathrm{~min}$. The homogenate was heated at $85{ }^{\circ} \mathrm{C}$ for $30 \mathrm{~min}$. The mixture was then subjected to centrifugation at $10,000 \mathrm{~g}$ for $15 \mathrm{~min}$ at room temperature (Model RC-B Plus centrifuge Newtown, CT, USA). Thereafter, $2.0 \mathrm{ml}$ of $0.2 \mathrm{M}$ phosphate buffer ( $\mathrm{pH} 8.2$ ) and $1.0 \mathrm{ml}$ of $0.01 \%$ (w/v) TNBS solution were added. The solution was mixed thoroughly and placed in a temperature-controlled water bath (Memmert, Schwabach, Germany) at $50{ }^{\circ} \mathrm{C}$ for $30 \mathrm{~min}$ in the dark. The reaction was terminated by adding $2.0 \mathrm{ml}$ of $0.1 \mathrm{M}$ sodium sulfite. The mixture was then cooled at room temperature for $15 \mathrm{~min}$. The absorbance was read at $420 \mathrm{~nm}$ and free amino group content was expressed in terms of L-leucine.

DH was calculated following the method of Benjakul and Morrissey (1997) with a slight modification as follows:

$$
\% \mathrm{DH}=\left(\mathrm{L} / \mathrm{L}_{\max }\right) \times 100
$$

where $L$ is the amount of free amino group in the product and $L_{\max }$ is the total free amino group after acid hydrolysis $\left(6 \mathrm{M} \mathrm{HCl}\right.$ at $100{ }^{\circ} \mathrm{C}$ for $\left.24 \mathrm{~h}\right)$.

Sodium dodecyl sulfate-polyacrylamide gel electrophoresis (SDS-PAGE)

Protein patterns were determined by SDS-PAGE using $4 \%$ stacking gel and $12.5 \%$ running gel, according to the method of Laemmli (1970). Samples (3 g) were solubilized in $27 \mathrm{ml}$ of $5 \%(\mathrm{w} / \mathrm{v}) \mathrm{SDS}\left(85^{\circ} \mathrm{C}\right)$. The mixture was homogenized for $1 \mathrm{~min}$ at a speed of $13,000 \mathrm{rpm}$ and incubated at $85{ }^{\circ} \mathrm{C}$ for $1 \mathrm{~h}$ to dissolve total proteins. Samples (15 $\mu \mathrm{g}$ protein) determined by the Biuret method (Robinson and Hogden 1940) were loaded onto the gel and subjected to electrophoresis at a constant current of $15 \mathrm{~mA}$ per gel using a Mini-Protean II unit (Bio-Rad Laboratories, Inc., Richmond, CA, USA). After electrophoresis, the gels were stained with $0.05 \%(\mathrm{w} / \mathrm{v})$ Coomassie Blue R-250 in $50 \%(\mathrm{v} / \mathrm{v})$ methanol and $7.5 \%(\mathrm{v} / \mathrm{v})$ acetic acid for 30 min. Finally, gels were destained with a mixture of $50 \%(\mathrm{v} / \mathrm{v})$ methanol and $7.5 \%(\mathrm{v} / \mathrm{v})$ acetic acid for $30 \mathrm{~min}$ and destained again with a mixture of $5 \%(\mathrm{v} / \mathrm{v})$ methanol and $7.5 \%(\mathrm{v} / \mathrm{v})$ acetic acid for $1 \mathrm{~h}$.

Analysis of carotenoid

Total carotenoid content in the samples was determined according to the method of Saito and Regier (1971) with a slight modification. Sample $(30 \mathrm{mg})$ was mixed with $10 \mathrm{ml}$ of petroleum ether and homogenized at a speed of 10,000 rpm for $1 \mathrm{~min}$. The homogenate was allowed to stand for $30 \mathrm{~min}$, followed by filtration using a Whatman filter paper No. 4 (Whatman International Ltd., Maidstone, UK). The absorbance of the filtrate, appropriately diluted, was read at 468 nm using a UV-1601 spectrophotometer (Shimadzu, Kyoto, Japan). The concentration $(C)$ of carotenoid in the sample was calculated using the equation given by Saito and Regier (1971) with a slight modification as follows:

$$
C(\mathrm{mg} / \mathrm{g} \text { lipids })=\frac{\mathrm{A}_{468} \times \text { volume of extract } \times \text { dilution factor }}{0.2 \times \text { weight of sample }(\mathrm{g})}
$$

where 0.2 is the $\mathrm{A}_{468}$ of $1 \mu \mathrm{g} / \mathrm{ml}$ standard astaxanthin.

The filtrate containing carotenoid was subjected to thin-layer chromatography (TLC) using activated $20 \times 20 \mathrm{~cm}$ silica gel plates (silica gel G type 60, Merck) following the modified procedure described by Sánchez-Camargo et al. (2011). The sample was applied on the plates, and the separation was carried out using a mixture of isopropanol and hexane $(50: 50, \mathrm{v} / \mathrm{v})$ as mobile phase. $\beta$-carotene and astaxanthin were used as standards.

Measurement of color

Color of salted shrimp paste was determined using a colorimeter (ColourFlex, Hunter Lab Reston, VA, USA) and reported in the CIE system. $L^{*}$ (lightness), $a^{*}$ (redness/greenness), and $b^{*}$ (yellowness/blueness) were reported. Additionally, $\Delta E^{*}$ (total difference of color) and $\Delta C^{*}$ (the difference in chroma) were calculated as follows: 


$$
\Delta E^{*}=\sqrt{\left(\Delta L^{*}\right)^{2}+\left(\Delta a^{*}\right)^{2}+\left(\Delta b^{*}\right)^{2}}
$$

where $\Delta L^{*}, \Delta a^{*}$ and $\Delta b^{*}$ are the differentials between color parameters of the samples and those of the white standard $\left(L^{*}=93.55, a^{*}=-0.84\right.$ and $\left.b^{*}=0.37\right)$.

$$
\Delta C^{*}=C_{\text {sample }}^{*}-C_{\text {standard }}^{*}
$$

where $C^{*}=\sqrt{\left(a^{*}\right)^{2}+\left(b^{*}\right)^{2}}$.

Statistical analysis

All analyses were conducted in triplicate. Statistical analysis was performed using one-way analysis of variance (ANOVA). Mean comparison was carried out using Duncan's multiple range test (Steel et al. 1980).

\section{Results and discussion}

Proximate compositions, $A_{\mathrm{w}}, \mathrm{pH}$ and salt content

Proximate compositions of different salted shrimp paste samples are shown in Table 1. Moisture content of salted shrimp paste samples varied from 33.79 to $52.54 \%$. Based on dry matter, protein constituted the major component (29.44-53.17\%), indicating that salted shrimp paste could be the good source of proteins. S11 (Kapi Samut Songkram) showed the highest protein content $(53.17 \%$ ) followed by S9 (Kapi Rayong) $(48.19 \%)$. All samples contained salt, which is needed for preservation. Salt content was in the range of $22.77-35.47 \%$. This contributed to high ash content of all samples (33.80-50.50 \%). S6 (Kapi Songkhla1) and S7 (Kapi Songkhla2) had the highest salt contents (35.47 and $34.44 \%$, respectively). This was in agreement with the highest ash contents (50.08 and $50.50 \%$, respectively). Slightly higher ash content, in comparison with salt content, was more likely attributed to the presence of inorganic substances in the shell of shrimp or krill used as raw material. Shell has been known to have $\mathrm{CaCO}_{3}$ as the component (Stevenson 1985). Fat contents of salted shrimp paste ranged from 1.41 to $3.67 \%$. Shrimp oil was reported to be rich in polyunsaturated fatty acid. Linoleic acid $(\mathrm{C} 18: 2(n-6))$ was the dominant fatty acid in shrimp oil from Pacific white shrimp (Takeungwongtrakul et al. 2012b). This made shrimp oil susceptible to lipid oxidation (Takeungwongtrakul and Benjakul 2013). Moreover, a wide range of carbohydrate content (4.90-32.48\%) was noticeable. S4 (Kapi Krabi1) had the highest carbohydrate content (32.48 \%). S1 (Kapi Satun) and S10 (Kapi Chachoengsao) also contained a high amount of carbohydrate (20.99 and $22.75 \%$, respectively). The difference in carbohydrate content could be obtained among the samples, dependent on the addition of polysaccharides by processors. They add the root crops, flour or sugar to increase the yield or improve the flavor and taste of shrimp paste (Faithong et al. 2010). Those components had the impact on quality attribute and nutritive value of salted shrimp paste. Faithong et al. (2010) reported that $\mathrm{pH}$, moisture, protein, fat, ash, salt and carbohydrate content of shrimp paste produced in the south of Thailand were 7.44-7.66, 36.78-49.93, 31.85-43.12, 2.42-4.10, 41.04-50.93, 19.29-24.73 and 4.58-24.70\% (dry weight basis), respectively.

Water activity $\left(A_{\mathrm{w}}\right)$ of shrimp paste was in the range of $0.669-0.774$, with corresponding low moisture content (Table 1). $A_{\mathrm{w}}$ can be related to the consistency of salted shrimp paste, which varied from soft and pasty to dry and hard. $A_{\mathrm{w}}$ of the final product would depend on how long the sample was allowed to dry under the sun. Furthermore, high salt level directly lowered $A_{\mathrm{w}}$ of products. Salted shrimp paste can be classified as an intermediate moisture food, with an $A_{\mathrm{w}}$ of about 0.7 (Fennema 1996). Lowered $A_{\mathrm{w}}$ could be associated with the prolonged shelf-life of salted shrimp paste (Goulas and Kontominas 2005). The samples had a $\mathrm{pH}$ range of 7.01-8.4. The slightly basic $\mathrm{pH}$ might have been caused by the degradation products generated during fermentation or the formation of volatile base compounds such as ammonia. When the hydrolysis proceeded, the small proteins or peptides might undergo decomposition, e.g., via deamination with ease. This could favor the formation of low-molecular weight basic compounds. 


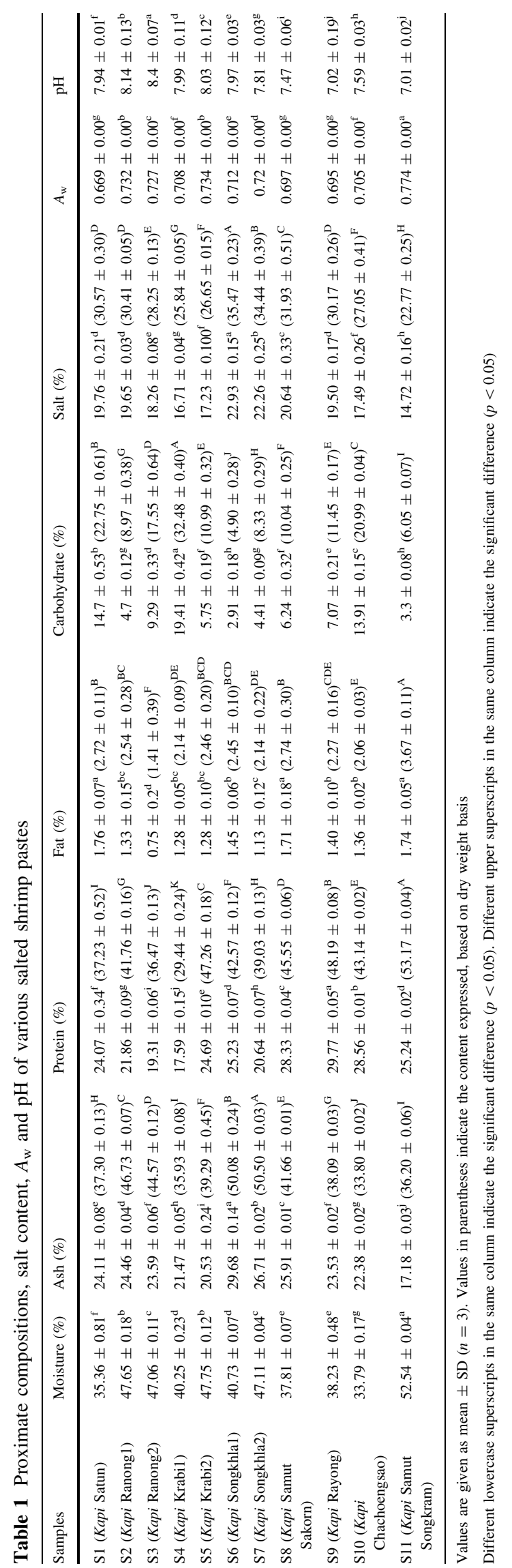


Table 2 Formal nitrogen, ammonia nitrogen, amino nitrogen contents and degree of hydrolysis of various salted shrimp pastes

\begin{tabular}{llllr}
\hline Samples & $\begin{array}{l}\text { Formal nitrogen content } \\
(\mathrm{mg} \mathrm{N} / \mathrm{g} \text { sample })\end{array}$ & $\begin{array}{l}\text { Ammonia nitrogen content } \\
(\mathrm{mg} \mathrm{N} / \mathrm{g} \text { sample })\end{array}$ & $\begin{array}{l}\text { Amino nitrogen content } \\
(\mathrm{mg} \text { N/g sample })\end{array}$ & $\begin{array}{l}\text { Degree of } \\
\text { hydrolysis }(\%)\end{array}$ \\
\hline S1 (Kapi Satun) & $15.42 \pm 0.35^{\mathrm{f}}$ & $0.56 \pm 0.01^{\mathrm{f}}$ & $14.85 \pm 0.35^{\mathrm{f}}$ & $16.61 \pm 0.03^{\mathrm{d}}$ \\
S2 (Kapi Ranong1) & $17.62 \pm 0.15^{\mathrm{e}}$ & $0.67 \pm 0.03^{\mathrm{e}}$ & $16.95 \pm 0.24^{\mathrm{e}}$ & $19.18 \pm 0.60^{\mathrm{c}}$ \\
S3 (Kapi Ranong2) & $21.03 \pm 0.97^{\mathrm{c}}$ & $0.59 \pm 0.01^{\mathrm{f}}$ & $20.44 \pm 0.97^{\mathrm{c}}$ & $20.08 \pm 0.29^{\mathrm{b}}$ \\
S4 (Kapi Krabi1) & $21.89 \pm 0.22^{\mathrm{b}}$ & $0.71 \pm 0.02^{\mathrm{de}}$ & $21.18 \pm 0.20^{\mathrm{b}}$ & $20.22 \pm 0.04^{\mathrm{b}}$ \\
S5 (Kapi Krabi2) & $19.43 \pm 0.58^{\mathrm{d}}$ & $0.60 \pm 0.03^{\mathrm{f}}$ & $18.83 \pm 0.58^{\mathrm{d}}$ & $19.29 \pm 0.15^{\mathrm{c}}$ \\
S6 (Kapi Songkhla1) & $22.87 \pm 0.27^{\mathrm{a}}$ & $0.88 \pm 0.02^{\mathrm{b}}$ & $21.99 \pm 0.26^{\mathrm{a}}$ & $20.76 \pm 0.15^{\mathrm{a}}$ \\
S7 (Kapi Songkhla2) & $21.40 \pm 0.33^{\mathrm{bc}}$ & $0.81 \pm 0.06^{\mathrm{c}}$ & $20.59 \pm 0.34^{\mathrm{bc}}$ & $20.1 \pm 0.08^{\mathrm{b}}$ \\
S8 (Kapi Samut Sakorn) & $22.78 \pm 0.28^{\mathrm{a}}$ & $0.69 \pm 0.02^{\mathrm{de}}$ & $22.08 \pm 0.24^{\mathrm{a}}$ & $20.76 \pm 0.21^{\mathrm{a}}$ \\
S9 (Kapi Rayong) & $14.73 \pm 0.17^{\mathrm{f}}$ & $0.81 \pm 0.01^{\mathrm{c}}$ & $13.93 \pm 0.17^{\mathrm{g}}$ & $16.49 \pm 0.09^{\mathrm{d}}$ \\
S10 (Kapi Chachoengsao) & $12.09 \pm 0.01^{\mathrm{g}}$ & $0.74 \pm 0.02^{\mathrm{d}}$ & $11.35 \pm 0.01^{\mathrm{h}}$ & $12.68 \pm 0.24^{\mathrm{e}}$ \\
S11 (Kapi Samut Songkram) & $11.96 \pm 0.31^{\mathrm{g}}$ & $0.99 \pm 0.01^{\mathrm{a}}$ & $10.97 \pm 0.33^{\mathrm{h}}$ & $12.81 \pm 0.16^{\mathrm{e}}$ \\
\hline
\end{tabular}

Values are given as mean $\pm \mathrm{SD}(n=3)$

Different lowercase superscripts in the same column indicate the significant difference $(p<0.05)$

Formal nitrogen, ammonia nitrogen and amino nitrogen contents

Formal nitrogen contents of different salted shrimp pastes are shown in Table 2. Formal nitrogen content varied from 11.96 to $22.87 \mathrm{mg} \mathrm{N} / \mathrm{g}$ sample. Generally, the formal nitrogen content has been used to indicate the degree of protein hydrolysis (Chaveesak et al. 1993). Formaldehyde can react with alpha amino group and ammonia, releasing the proton which can be titrated with alkaline solution. Thus, formal nitrogen content can be the indicator for the level of the cleavage of peptides (Angeles and Garcia-Carreno 2002). The highest formal nitrogen contents were found in S6 (Kapi Songkhla1) and S8 (Kapi Samut Sakorn) $(p<0.05)$. The lowest value was found in S10 (Kapi Chachoengsao) and S11 (Kapi Samut Songkram) $(p<0.05$ ).

Ammonia nitrogen contents of all samples were in the range of $0.56-0.99 \mathrm{mg} \mathrm{N} / \mathrm{g}$ sample (Table 2). The ammonia nitrogen content indicates the breakdown of protein and peptides into free amino acid and volatile nitrogen (Lopetcharat et al. 2001; Binsan et al. 2008). Therefore, the differences in ammonia nitrogen contents among samples might be related with different proteolytic activity, both endogenous proteinase and microbial proteinase, during fermentation. The volatile nitrogenous compounds might contribute to different characteristics of the products, especially flavor. S11 (Kapi Samut Songkram) had the highest ammonia nitrogen content $(p<0.05)$.

Amino nitrogen contents of salted shrimp pastes from different provinces of Thailand are shown in Table 2 . Amino nitrogen content was calculated based on the differences between formal nitrogen content and ammonia nitrogen content. The amino nitrogen content represents the amount of primary amino group of the sample. An increase in amino nitrogen content is related to the degradation of polypeptide (Lopetcharat et al. 2001; Binsan et al. 2008). Generally, amino nitrogen content was in agreement with the formal nitrogen content. The result reconfirmed that higher cleavage of peptides was obtained in S6 (Kapi Songkhla1) and S8 (Kapi Samut Sakorn).

\section{Degree of hydrolysis}

Degree of hydrolysis (DH) of all samples varied (Table 2). DH is the measure of the extent of cleavage of peptide linkages. DH close to $100 \%$ means that all proteins in the sample are completely hydrolyzed to free amino acids (Panyam and Kilara 1996). DH of the samples was from 12.68 to $20.76 \%$. DH was in agreement with formal nitrogen content and amino nitrogen content. S6 (Kapi Songkhla1) and S8 (Kapi Samut Sakorn) showed the highest DH (20.76 \%) and S10 (Kapi Chachoengsao) and S11 (Kapi Samut Songkram) had the lowest DH (12.68 and $12.81 \%$, respectively). Due to different raw materials, processing condition and time of fermentation as well as different types or levels of proteolytic enzymes, varying degrees of cleavage were presumed. Products with different DH might possess different characteristics, taste, flavor, color and other 
attributes. Free amino groups available were able to undergo several reactions, e.g., Maillard reaction, thereby affecting the color or browning of products.

Protein patterns

Protein patterns of different salted shrimp pastes are shown in Fig. 1. All samples had proteins or peptides with molecular weight lower than $100 \mathrm{kDa}$. Major proteins were found in the range of 10-15 kDa. It was noted that Kapi Samut Songkram (S11) had the proteins with MW of 65 and $30 \mathrm{kDa}$. This coincided with the lowest DH of those samples. The results indicated the differences in protein pattern in individual sample. For all samples, there were no myosin heavy chain (MHC) and actin bands retained. This suggested that MHC and actin underwent degradation completely through proteolysis during fermentation in all samples. It has been reported that MHC was the most susceptible muscle proteins (Benjakul et al. 1997). When MHC was not available, actin can be hydrolyzed (Riebroy et al. 2008). It was also found that troponin and tropomyosin also disappeared in all samples. Krill and shrimp were found to contain serine protease and metalloprotease (Garcia-Carreño et al. 1994). Those proteases along with proteases from halophilic bacteria more likely played a role in hydrolysis of proteins in raw material. With intensive degradation, free amino acids or low-molecular weight peptides can be produced. The formation of low-molecular weight peptides or proteins was in accordance with the increasing DH, formal nitrogen and amino nitrogen contents (Table 2).

Carotenoid

\section{Carotenoid content}

Total carotenoid contents in different salted shrimp pastes are shown in Table 3. Carotenoids, especially astaxanthin, provide the desirable reddish-orange color in crustaceans (Higuera-Ciapara et al. 2006). Carotenoid content of salted shrimp pastes varied from 0.54 to $1.97 \mathrm{mg} / \mathrm{g}$ lipid. Among all samples, S7 (Kapi Songkhla2) had the highest total carotenoid content $(1.97 \mathrm{mg} / \mathrm{g}$ lipid) $(p<0.05)$, whereas S11 (Kapi Samut Songkram) $(0.54 \mathrm{mg} / \mathrm{g}$ lipid) and S6 (Kapi Songkhla1) $(0.69 \mathrm{mg} / \mathrm{g}$ lipid) had the lowest carotenoid content $(p<0.05)$. The differences in carotenoid content could plausibly be to the different raw materials used. Shrimp with different species and feed used showed varying carotenoid content (Shahidi and Brown 1998). Supplementation of carotenoids in red porgy (Pagrus pagrus) could increase redness, yellowness and chroma of their skin (Manganaro et al. 2012). Additionally, stability of carotenoid in different samples could be varied, depending on the process or other factors involved. Carotenoid content of hepatopancreas of Pacific white

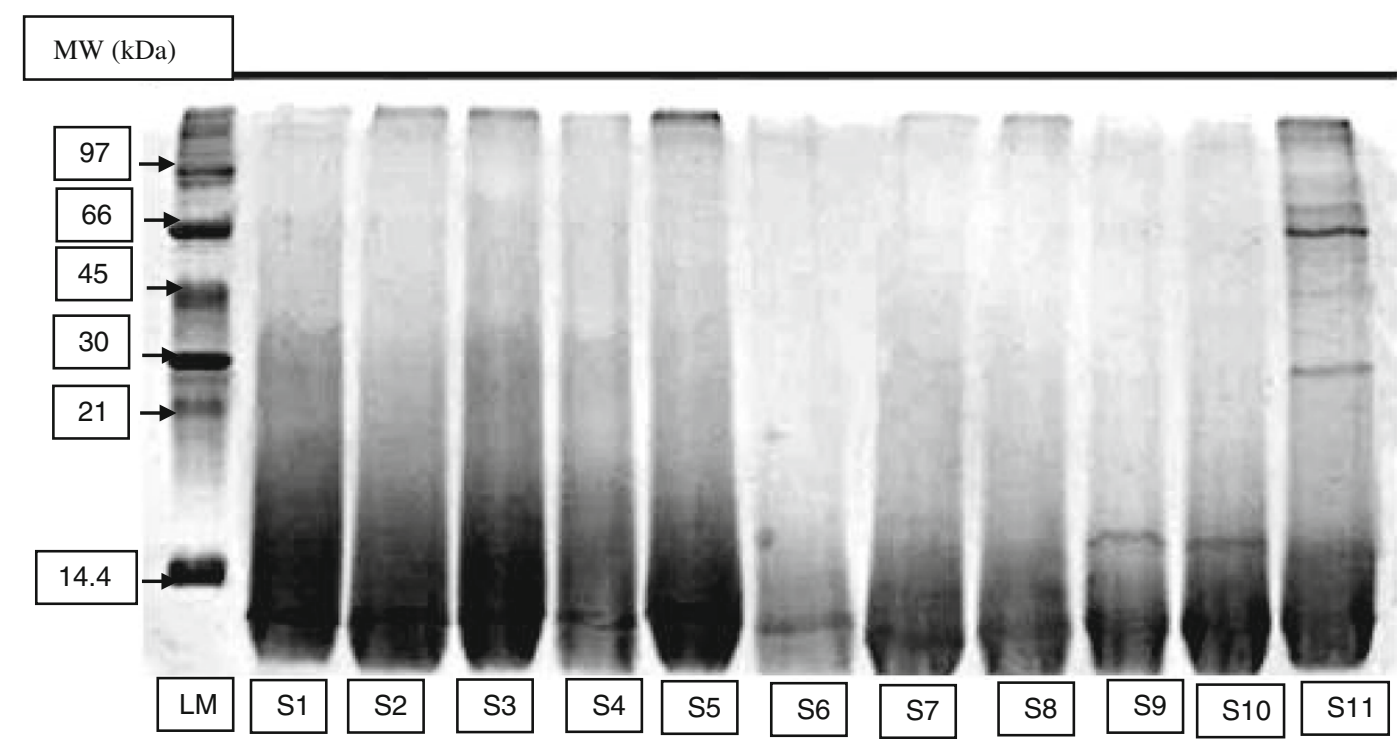

Fig. 1 Protein patterns of various salted shrimp pastes, $L M$ low-molecular weight marker, key: see Table 1 caption 
Table 3 Carotenoid content and colors of various salted shrimp pastes

\begin{tabular}{|c|c|c|c|c|c|c|}
\hline Samples & $\begin{array}{l}\text { Carotenoid } \\
\text { content } \\
\text { (mg/g sample) }\end{array}$ & $L^{*}$ & $a^{*}$ & $b^{*}$ & $\Delta E^{*}$ & $\Delta C^{*}$ \\
\hline S1 (Kapi Satun) & $1.41 \pm 0.04^{\mathrm{c}}$ & $42.37 \pm 0.05^{\mathrm{e}}$ & $15.39 \pm 0.07^{\mathrm{a}}$ & $13.49 \pm 0.17^{\mathrm{b}}$ & $55.27 \pm 0.07^{\mathrm{d}}$ & $19.55 \pm 0.11^{\mathrm{b}}$ \\
\hline S2 (Kapi Ranong1) & $1.19 \pm 0.03^{\mathrm{e}}$ & $46.74 \pm 0.04^{\mathrm{b}}$ & $12.13 \pm 0.17^{\mathrm{c}}$ & $11.86 \pm 0.21^{\mathrm{d}}$ & $49.92 \pm 0.03^{\mathrm{h}}$ & $16.05 \pm 0.04^{\mathrm{d}}$ \\
\hline S3 (Kapi Ranong2) & $1.32 \pm 0.08^{\mathrm{d}}$ & $51.84 \pm 0.04^{\mathrm{a}}$ & $12.68 \pm 0.03^{\mathrm{b}}$ & $17.59 \pm 0.07^{\mathrm{a}}$ & $47.10 \pm 0.01^{\mathrm{i}}$ & $20.76 \pm 0.06^{\mathrm{a}}$ \\
\hline S4 (Kapi Krabi1) & $1.35 \pm 0.06^{\mathrm{d}}$ & $38.5 \pm 0.07^{\mathrm{i}}$ & $11.3 \pm 0.02^{\mathrm{d}}$ & $10.87 \pm 0.10^{\mathrm{e}}$ & $57.35 \pm 0.06^{\mathrm{b}}$ & $14.76 \pm 0.04^{\mathrm{e}}$ \\
\hline S5 (Kapi Krabi2) & $1.95 \pm 0.03^{\mathrm{a}}$ & $43.37 \pm 0.05^{\mathrm{d}}$ & $9.7 \pm 0.17^{\mathrm{e}}$ & $12.03 \pm 0.19^{\mathrm{d}}$ & $52.58 \pm 0.03^{\mathrm{f}}$ & $14.54 \pm 0.08^{\mathrm{e}}$ \\
\hline S6 (Kapi Songkhla1) & $0.69 \pm 0.02^{\mathrm{f}}$ & $39.34 \pm 0.08^{\mathrm{h}}$ & $5.24 \pm 0.06^{\mathrm{h}}$ & $9.91 \pm 0.24^{\mathrm{f}}$ & $55.38 \pm 0.11^{\mathrm{c}}$ & $10.29 \pm 0.20^{\mathrm{g}}$ \\
\hline S7 (Kapi Songkhla2) & $1.97 \pm 0.02^{\mathrm{a}}$ & $44.65 \pm 0.06^{\mathrm{c}}$ & $11.81 \pm 0.07^{\mathrm{c}}$ & $12.92 \pm 0.17^{\mathrm{c}}$ & $52.05 \pm 0.03^{\mathrm{g}}$ & $16.59 \pm 0.17^{\mathrm{c}}$ \\
\hline S8 (Kapi Samut Sakorn) & $1.53 \pm 0.03^{\mathrm{b}}$ & $34.13 \pm 0.06^{\mathrm{j}}$ & $8.34 \pm 0.07^{\mathrm{f}}$ & $6.39 \pm 0.20^{\mathrm{i}}$ & $60.43 \pm 0.08^{\mathrm{a}}$ & $9.59 \pm 0.10^{\mathrm{h}}$ \\
\hline S9 (Kapi Rayong) & $1.51 \pm 0.01^{\mathrm{b}}$ & $39.91 \pm 0.05^{\mathrm{f}}$ & $9.75 \pm 0.58^{\mathrm{e}}$ & $7.6 \pm 0.14^{\mathrm{g}}$ & $55.16 \pm 0.08^{\mathrm{e}}$ & $11.45 \pm 0.40^{\mathrm{f}}$ \\
\hline S10 (Kapi Chachoengsao) & $1.43 \pm 0.02^{\mathrm{c}}$ & $39.36 \pm 0.08^{\mathrm{h}}$ & $7.46 \pm 0.04^{\mathrm{g}}$ & $7.21 \pm 0.23^{\mathrm{h}}$ & $55.24 \pm 0.08^{\mathrm{de}}$ & $9.46 \pm 0.13^{\mathrm{h}}$ \\
\hline $\begin{array}{l}\text { S11 (Kapi Samut } \\
\text { Songkram) }\end{array}$ & $0.54 \pm 0.01^{\mathrm{g}}$ & $39.53 \pm 0.03^{\mathrm{g}}$ & $9.43 \pm 0.11^{\mathrm{e}}$ & $4.56 \pm 0.09^{j}$ & $55.15 \pm 0.02^{\mathrm{e}}$ & $9.56 \pm 0.07^{\mathrm{h}}$ \\
\hline
\end{tabular}

Values are given as mean $\pm \mathrm{SD}(n=3)$

Different lowercase superscripts in the same column indicate the significant difference $(p<0.05)$

shrimp was $336.40 \mathrm{mg} / \mathrm{kg}$ sample (Takeungwongtrakul et al. 2012a). Sachindra et al. (2006) reported the highest carotenoid content $(43.9 \mathrm{mg} / \mathrm{kg}$ sample) from head and carapace of Penaeus indicus when 50:50 (v/v) mixture of hexane and isopropanol was used as extracting medium. The variation in carotenoids in crustaceans is caused by various factors such as species, feed, parts of body, environmental condition and other variables (Mezzomo et al. 2011; Takeungwongtrakul et al. 2012b). Apart from protein, carotenoids have paid increasing interest as the important source of antioxidants from crustaceans (De Holanda and Netto 2006). The presence of carotenoids in salted shrimp pastes indicated that carotenoids were stable during fermentation under the high salt environment. In general, carotenoids were associated with protein as carotenoprotein (ArmentaLópez et al. 2002). When proteins were degraded, free carotenoids were released and might undergo oxidation to some extent. These carotenoids more likely contributed to color of salted shrimp paste to some degree. Carotenoid in shrimp was reported to possess antioxidative activity (Bustos et al. 2003; Sowmya and Sachindra 2012).

\section{Thin-layer chromatography (TLC)}

Carotenoids in salted shrimp paste were separated by TLC (Fig. 2). Similar TLC chromatograms were observed among different samples. The major bands with $R_{\mathrm{f}}$ of $0.33,0.40$ and 0.75 were observed, corresponding to free astaxanthin, canthaxanthin and astaxanthin diester, respectively. The $R_{\mathrm{f}}$ of cantaxanthin was in agreement with that reported by Todd (1998), in which $R_{\mathrm{f}}$ of 0.40 was obtained. Kobayashi and Sakamoto (1999) reported that astaxanthin diester had $R_{\mathrm{f}}$ in range of 0.75-0.85. Shahidi and Brown (1998) and Sachindra et al. (2001) also reported that astaxanthin and its esters are the major carotenoids in the marine crustaceans. It was noted that carotenoid in different samples varied in terms of components. No canthaxanthin was found in S11 (Kapi Samut Songkram). Also, proportion of those components varied with samples. The results suggested that raw materials used for production of salted shrimp paste were different. As a result, carotenoids in the resulting products varied in composition. This might affect physical properties and bioactivity of products.

\section{Color}

The different salted shrimp pastes had different colors. $L^{*}$ (lightness), $a^{*}$ (redness), $b^{*}$ (yellowness), $\Delta E^{*}$ (total difference in color) and $\Delta C^{*}$ (difference in chroma) were in the range of 34.13-51.84, 5.24-15.39, 4.56-17.59, 47.10-60.43 and 9.46-20.76, respectively. S8 (Kapi Samut Sakorn) had the lowest $L^{*}$ and the highest $\Delta E^{*}$. The lowest $\Delta C^{*}$ was also noticeable in this sample. This sample was brown in color. On the other hand, S1 (Kapi Satun) had the highest $a^{*}$ value, whereas S3 (Kapi Ranong2) showed the highest $b^{*}$ value $(p<0.05)$. S3 


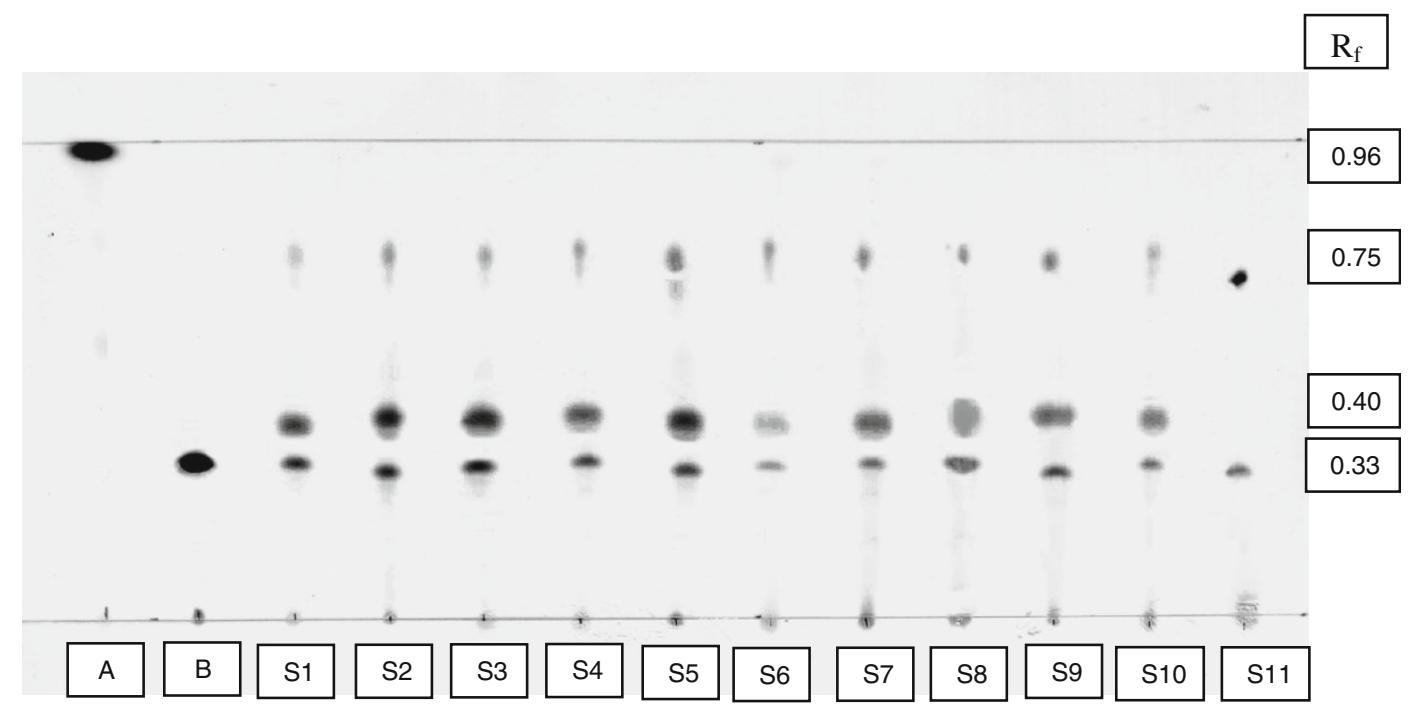

Fig. 2 Thin-layer chromatogram of carotenoids from various salted shrimp pastes ( $A \beta$-carotene, $B$ astaxanthin. Key: see Table 1 caption

(Kapi Ranong2) also exhibited the highest $\Delta C^{*}$ value $(p<0.05)$. The difference in color might be caused by the different pigment contents, as determined by raw materials, process as well as ingredients added. Highest $a^{*}$ value for Kapi Satun was in agreement with the highest total carotenoid content (Table 3). Generally, lipid oxidation was associated with browning mediated by Maillard reaction (Yarnpakdee et al. 2012). The carbonyl groups of aldehydes and ketone, the oxidation products, could react with amino groups of free amino acids or peptides generated during hydrolysis, leading to yellow or brown color development (Yarnpakdee et al. 2014). DH in each product might, therefore, be related with different colors.

\section{Conclusion}

Different salted shrimp pastes had varying compositions. However, protein constituted the major component in all samples. Hydrolysis of proteins took place at different degrees, leading to varying protein or peptide. Carotenoids were also found as the components, which partially contributed to color. Studies on sensory properties, and flavor profile of salted shrimp pastes are ongoing, in which desirable characteristic for this product can be gained.

Acknowledgments This research was supported by Prince of Songkla University and the Grant-in-Aid for dissertation from Graduate School, Prince of Songkla University, Thailand. The TRF senior research scholar program was also acknowledged for the financial support.

Conflict of interest The authors declare that they have no competing interests.

Author's contributions SB developed the initial idea and designed the study. SB and JP carried out the analytical work. JP wrote the manuscript with assistance from SB. SB, OK and NF read and approved the final manuscript.

Open Access This article is distributed under the terms of the Creative Commons Attribution License which permits any use, distribution, and reproduction in any medium, provided the original author(s) and the source are credited.

\section{References}

Angeles Navarrete del Toro M, Garcia-Carreno FL (2002) Evaluation of the progress of protein hydrolysis. In: Wrolstad RE et al (eds) Current protocols in food analytical chemistry. Wiley, New York

AOAC (2000) Official method of analysis. Association of official chemists, Gaithersburg 
Armenta-López R, Guerrero IL, Huerta S (2002) Astaxanthin extraction from shrimp waste by lactic fermentation and enzymatic hydrolysis of the carotenoprotein complex. J Food Sci 67:1002-1006

Benjakul S, Morrissey MT (1997) Protein hydrolysates from Pacific whiting solid wastes. J Agric Food Chem 45:3423-3430

Benjakul S, Seymour TA, Morissey MT, An H (1997) Physicochemical changes in Pacific whiting muscle proteins during iced storage. J Food Sci 62:729-733

Binsan W, Benjakul S, Visessanguan W, Roytrakul S, Tanaka M, Kishimura H (2008) Antioxidative activity of Mungoong, an extract paste, from the cephalothorax of white shrimp (Litopenaeus vannamei). Food Chem 106:185-193

Bustos R, Romo L, Yanez K, Diaz G, Romo C (2003) Oxidative stability of carotenoid pigments and polyunsaturated fatty acids in microparticulate diets containing krill oil for nutrition of marine fish larvae. J Food Eng 56:289-293

Chaveesak R, Smith JP, Simpson BK (1993) Production of fish sauce and acceleration of sauce fermentation using proteolytic enzymes. J Aquat Food Prod Technol 2(3):59-77

De Holanda HD, Netto FM (2006) Recovery of components from shrimp (Xiphopenaeus kroyeri) processing waste by enzymatic hydrolysis. J Food Sci 71:298-303

Faithong N, Benjakul S, Phatcharat S, Binson W (2010) Chemical composition and antioxidative activity of Thai traditional fermented shrimp and krill products. Food Chem 119:133-140

Fennema OR (1996) Water and ice. In: Fennema OR (ed) Food chem. Marcel Dekker, New York, pp 17-94

Garcia-Carreño FL, Patricia Hernandez-Cortes M, Haard NF (1994) Enzymes with peptidase and proteinase activity from the digestive systems of a freshwater and a marine decapod. J Agric Food Chem 42:1456-1461

Goulas AE, Kontominas MG (2005) Effect of salting and smoking-method on the keeping quality of chub mackerel (Scomber japonicus): biochemical and sensory attributes. Food Chem 93:511-520

Hajeb P, Jinap S (2013) Umami taste components and their sources in Asian foods. Crit Rev Food Sci 8:1102-1115

Higuera-Ciapara I, Felix-Valenzuela L, Goycoolea FM (2006) Astaxanthin: a review of its chemistry and applications. Crit Rev Food Sci Nutr 46:185-196

Kobayashi M, Sakamoto Y (1999) Singlet oxygen quenching ability of astaxanthin esters from the green alga Haematococcus pluvialis. Biotechnol Lett 21:265-269

Laemmli UK (1970) Cleavage of structural proteins during the assembly of the head of bacteriophage T4. Food Microbiol 227:680-685

Lopetcharat K, Choi YJ, Park JW, Daeschel MA (2001) Fish sauce products and manufacturing: a review. Food Rev Int 17:65-88

Manganaro A, Sanfilippo M, Fortino G, Dapra F, Palmegiano GB, Gai F (2012) Artificial pigmentation and flesh quality in red porgy (Pagrus pagrus). Int Aquat Res 4:1-12

Mezzomo N, Maestri B, Dos Santos RL, Maraschin M, Ferreira SRS (2011) Pink shrimp (P. brasiliensis and P. paulensis) residue: influence of extraction method on carotenoid concentration. Talanta 85:1383-1391

Mizutani T, Kimizuka A, Ruddle K, Ishige N (1987) A chemical analysis of fermented fish products and discussion of fermented flavors in Asian cuisines. In: Atsushi N (ed) Bulletin of the national museum of ethnology, vol 12. Osaka, Japan, pp 801-864

Nirmal NP, Benjakul S (2009) Effect of ferulic acid on inhibition of polyphenoloxidase and quality changes of Pacific white shrimp (Litopenaeus vannamei) during iced storage. Food Chem 116:323-331

Panyam D, Kilara A (1996) Enhancing the functionality of food proteins by enzymatic modification. Trends Food Sci Techol $7: 120-125$

Peralta EM, Hatate H, Kawabe D, Kuwahara R, Wakamatsu S, Yuki T, Murata H (2008) Improving antioxidant activity and nutritional components of Philippine salt-fermented shrimp paste through prolonged fermentation. Food Chem 111:72-77

Phithakpol B (1993) Fish fermentation technology in Thailand. In: Steinkraus KH, Reilly PJ (eds) Fish fermentation technology. United Nation University Press, Tokyo, pp 155-166

Phithakpol B, Kasetsat M (1995) The traditional fermented foods of Thailand. Institute of food research and product development, Kasetsart University, Bangkok

Riebroy S, Benjakul S, Visessanguan W (2008) Properties and acceptability of Som-fug, a Thai fermented fish mince, inoculated with lactic acid bacteria starters. LWT-Food Sci Technol 41:569-580

Robinson HW, Hogden CG (1940) The biuret reaction in the determination of serum proteins: measurements made by a Duboscq colorimeter compared with values obtained by the Kjeldahl procedure. J Biol Chem 135:727-731

Sachindra NM, Bhaskar N, Sakhare PZ, Mahendrakar NS, Narasimha Rao D (2001) An improved process for recovery of carotenoids from crustacean waste. Indian Patent 95/DEL/2001, 31 Jan 2001

Sachindra NM, Bhaskar N, Mahendrakar NS (2006) Recovery of carotenoids from shrimp waste in organic solvents. Waste Manag 26:1092-1098

Saito A, Regier L (1971) Pigmentation of brook trout (Salvelinus fontinalis) by feeding dried crustacean waste. J Fish Res Board Can 28:509-512

Sánchez-Camargo AP, Almeida-Meireles MÂ, B-Lopes LF, Cabral FA (2011) Proximate composition and extraction of carotenoids and lipids from Brazilian redspotted shrimp waste (Farfantepenaeus paulensis). J Food Eng 102:87-93

Shahidi F, Brown JA (1998) Carotenoid pigments in seafoods and aquaculture. Crit Rev Food Sci Nutr 38:1-67

Sowmya R, Sachindra NM (2012) Evaluation of antioxidant activity of carotenoid extract from shrimp processing by products by in vitro assays and in membrane model system. Food Chem 134:308-314

Steel RGD, Torrie JH, Dickey DA (1980) In: Steel RGD (ed) Principle and procedure of statistics. McGraw-Hill, New York, pp 457-490

Stevenson JR (1985) Integument, pigments and hormonal processes. In: Bliss DE, Mantel LH (eds) The biology of Crustacea, vol 9. Academic Press, New York, p 1

Takeungwongtrakul S, Benjakul S (2013) Oxidative stability of shrimp oil-in-water emulsions as affected by antioxidant incorporation. Int Aquat Res 5:1-12 
Takeungwongtrakul S, Benjakul S, Santoso J, Trilaksani W, Nurilmala M (2012a) Extraction and stability of carotenoidcontaining lipids from Hepatopancreas of Pacific white shrimp (Litopenaeus vannamei). J Food Process Preserv 71:1-9

Takeungwongtrakul S, Benjakul S, H-Kittikun A (2012b) Lipids from cephalothorax and hepatopancreas of Pacific white shrimp (Litopenaeus vannamei): compositions and deterioration as affected by iced storage. Food Chem 134:2066-2074

Tamang JP, Kailasapathy K (2010) Fermented foods and beverages of the world. CRC Press Inc, New York

Thai Industrial Standard (1983) Local fish sauce standard. Department of Industry, Bangkok

Todd L (1998) Thin layer chromatography (TLC) system for Natu Rose carotenoids. Natu Rose Tech Bull 3:1-3

Yarnpakdee S, Benjakul S, Kristinsson HG, Maqsood S (2012) Effect of pretreatment on lipid oxidation and fishy odour development in protein hydrolysates from the muscle of Indian mackerel. Food Chem 135:2474-2482

Yarnpakdee S, Benjakul S, Penjamrus P, Kristinsson HG (2014) Chemical compositions and muddy flavour/odour of protein hydrolysate from Nile tilapia and broadhead catfish mince and protein isolate. Food Chem 142:210-216 